\title{
EDUCATING YOUNG CHILDREN IN WPA NURSERY SCHOOLS
}

FEDERALLY FUNDED EARLY CHILDHOOD EDUCATION FROM 1933-1943

\section{Molly Quest Arboleda}

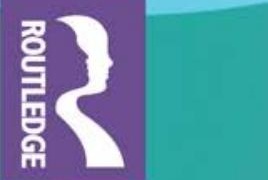




\section{Educating Young Children in WPA Nursery Schools}

Educating Young Children in WPA Nursery Schools, the first full-length national study of the WPA nursery school program, helps to explain why universal preschool remains an elusive goal. This book argues that program success in operating nursery schools throughout the United States during the Great Depression was an important New Deal achievement. By highlighting the program's strengths-its ideals, its curriculum, and its community outreach - the author offers a blueprint for creating a universal preschool program that benefits both children and their families. This volume uncovers the forgotten perspective of WPA nursery school leaders and highlights the program's innovative curriculum for young children by incorporating both extensive archival research and neglected sources.

Molly Quest Arboleda received a PhD in History from Claremont Graduate University, US. 


\section{Routledge Research in Education}

This series aims to present the latest research from right across the field of education. It is not confined to any particular area or school of thought and seeks to provide coverage of a broad range of topics, theories and issues from around the world.

Recent titles in the series include:

Creativity and Learning in Later Life An Ethnography of Museum Education Shari Sabeti

Teachers and Teacher Unions in a Globalised World International Perspectives on the Schooled Society Edited by Julian Sefton-Green and Ola Erstad

Researching and Enacting Change in Postsecondary Education Leveraging Instructors' Social Networks Edited by Charles Henderson, Chris Rasmussen, Alexis V. Knaub, Naneh Apkarian, Kathleen Quardokus Fisher, and Alan J. Daly

Education and Muslim Identity During a Time of Tension Inside an American Islamic School

Melanie C. Brooks

Moral Thought and Educational Practice

Hugh T. Sockett

Educating Young Children in WPA Nursery Schools

Federally Funded Early Childhood Education from 1933-1943

Molly Quest Arboleda

For a complete list of titles in this series, please visit www.routledge.com/ Routledge-Research-in-Education/book-series/SE0393 


\section{Educating Young Children in WPA Nursery Schools \\ Federally Funded Early Childhood Education from 1933-1943}

Molly Quest Arboleda 
First published 2019

by Routledge

711 Third Avenue, New York, NY 10017

and by Routledge

2 Park Square, Milton Park, Abingdon, Oxon, OX14 4RN

Routledge is an imprint of the Taylor \& Francis Group, an informa business

(C) 2019 Taylor \& Francis

The right of Molly Quest Arboleda to be identified as author of this work has been asserted by her in accordance with sections 77 and 78 of the Copyright, Designs and Patents Act 1988.

All rights reserved. No part of this book may be reprinted or reproduced or utilised in any form or by any electronic, mechanical, or other means, now known or hereafter invented, including photocopying and recording, or in any information storage or retrieval system, without permission in writing from the publishers.

Trademark notice: Product or corporate names may be trademarks or registered trademarks, and are used only for identification and explanation without intent to infringe.

Library of Congress Cataloguing-in-Publication Data A catalog record for this book has been requested

ISBN: 978-0-815-38384-0 (hbk)

ISBN: 978-1-351-20535-1 (ebk)

Typeset in Sabon

by Apex CoVantage, LLC 
To my children, Andrew and Katherine

To early childhood educators-past, present, and future 


\section{Contents}

List of Figures and Tables viii

Acknowledgments ix

$\begin{array}{ll}\text { Introduction } & 1\end{array}$

1 WPA Nursery Schools as Educational Reform 17

2 American Modernism and the WPA Nursery School Curriculum $\quad 45$

3 The WPA Nursery School and the Community 79

4 In Time of War 105

5 Buried Treasure 133

$\begin{array}{ll}\text { Index } & 161\end{array}$ 


\section{Figures and Tables}

Figures

0.1 Young Children Playing 10

$1.1 \quad$ Grace Langdon as National Director 26

1.2 Eleanor Roosevelt Visiting a WPA Nursery School 27

1.3 WPA Nursery School Teacher with Students 32

$2.1 \quad$ Before and After 49

2.2 The Built Environment 51

2.3 Health Inspections $\quad 52$

$2.4 \quad$ Plenty of Rest 53

$2.5 \quad$ Nutritious Meals 55

2.6 Fresh Air and Sunshine 57

2.7-2.9 Opening the Door of the Arts 59

$2.10 \quad$ Homemade Toys 61

2.11-2.12 Raw Materials $\quad 62$

2.13-2.14 Blocks, the Favorite Toy 64

2.15 Program Showcase at the 1939 New York World's Fair 66

3.1 Manzanar Nursery School 82

3.2 Arthurdale Nursery School 85

3.3 WPA Neighborhood Preschools 92

4.1 Langdon's Advisory Committee 117

4.2 Politicized Childcare 118

5.1 Smear Campaigns 145

Table

3.1 Nationwide Distribution of WPA Nursery Schools 80 


\section{Acknowledgments}

Thank you to Janet Brodie, Hal Barron, and Julia Mickenberg for believing in me years ago. Thank you to Al Arboleda, Andrea Grasso, Sandy HardieTownsend, Jennifer Helgren, Charles Kerchner, Rebecca Kimitch, and Ben Quest for providing words of encouragement this past year as I wrote this manuscript. A very special thanks to Amy E. Davis, who beautifully lineedited. And finally, thank you to all of the archivists who created highresolution images for me recently at the Claremont Colleges Library Special Collections, CSUN Oviatt Library Special Collections, FDR Presidential Library, The Herb Block Foundation, Library of Congress, National Archives, New Orleans Public Library, and the Walter P. Reuther Library, Wayne State University.

I am finishing this work of history seventy-five years after the demise of the WPA nursery school program. I hope its publication revitalizes discussion of why universal preschool is important. Thank you in advance for reading.

Molly Quest Arboleda

April 2018 


\section{Introduction}

The Works Progress Administration (WPA) nursery school program transformed the lives of those it served and early childhood education itself. Not until Head Start in the 1960s would the nation again attempt to provide a similar program for children and families in need. The WPA's nursery schools, the first federally funded preschool education program in the United States, proved popular at the local level, and for nearly ten years, WPA nursery schools provided instruction for roughly 50,000 children annually in more than 1,500 schools nationwide. ${ }^{1}$ Under the leadership of Grace Langdon, who held a doctorate from Columbia Teachers College, WPA nursery schools became models of early childhood education, and its administrators fully expected their program to lead to public preschools for all young children. ${ }^{2}$

WPA nursery schools revolutionized the care of young children with practices that often became the norm and remain in use today. Yet the program has been only briefly mentioned in histories of children, women, the New Deal, and progressive education. Never studied as the education reform it was, its innovative curriculum has not been analyzed, and its effort to cultivate community activism goes unrecognized.

This book examines the program's contributions to children, their families and communities, and progressive education. It also investigates the politicization of the program, which began with the Dies Committee investigation of the WPA in 1938, escalated into World War II-era attacks against government daycare for working mothers, and culminated with charges of communist leanings of its proponents during the Red Scare. WPA nursery school leaders helped create a supportive coalition comprising left-leaning men and women from the New Deal, the Congress of Industrial Organizations (CIO), and advocates for progressive education, civil rights, and the peace movement. ${ }^{3}$ By exploring the overlapping networks of reformers often overlooked in New Deal scholarship, this book deepens our awareness of interwar progressive reform.

Scholars present a one-sided and often distorted account of the WPA nursery school program because they use the writings of groups that were, at best, lukewarm supporters. Those who do not ignore the program 


\section{Introduction}

altogether shine their spotlights on the World War II childcare program, basing their interpretations on primary sources from the program's waning years, when political rivalries contributed to the program's demise. In the end, we neglect its rich history of progressive idealism, children's play, and community building. In addition, the viewpoints of social workers dominate scholarship on the WPA nursery school program. Studies generally make claims using information obtained from the Children's Bureau (CB) and archival holdings of the Federal Security Agency, the agency that tried to take control of the WPA's nursery school program during World War II. ${ }^{4}$

Explanations given for the program's failure to thrive show the use of tainted evidence. ${ }^{5}$ Women's historians, in particular, appear to accept uncritically the notion that a group care ethos did not exist prior to World War II. Others focus on the WPA as a New Deal agency providing temporary work relief. This perspective suggests that because the WPA was constructed as an emergency measure, any expectations for permanence were foolish. Yet after World War II, Congress institutionalized other WPA projects, such as the school-lunch program. Some scholars claim that the WPA nursery school program failed because parents lacked interest in "socialistic group care" for children. I have found no evidence that the majority of Americans from 1933-1943 believed group care smacked of socialism, although certain kinds of anti-communism helped derail the program. ${ }^{6}$

This book uncovers the forgotten perspective of WPA nursery school leaders using both extensive archival research and neglected sources such as the journals Childhood Education and Progressive Education. Its corrections to previous works are based in part on the most complete survey yet of extant WPA nursery school literature. ${ }^{7}$ The book's scope extends to perspectives besides those of WPA nursery school leaders and social welfare advocates. The analysis begins in 1920, when Patty Smith Hill ushered in the American nursery school movement. I identify which groups (like progressive educators) were early proponents of nursery schools and which (such as child welfare workers) were not. I use brief case studies to investigate the fate of the program in three states: California, Kentucky, and New York. To explore one of the least understood political battles of World War II-that over the 1943 hearings on the Thomas Bill addressing "Wartime Care and Protection of Children of Employed Mothers"-I turn to under-utilized congressional documents from hearings on federal aid to education and appropriations, WPA archival material, Grace Langdon's correspondence, and WPA literature by former bohemian radical Floyd Dell to delineate more clearly the issues that preoccupied those fighting over the program.

Background on psychology, anthropology, early childhood education, and folklore provides a deeper contextualization for investigating the lives of WPA nursery school children. ${ }^{8}$ WPA nursery school toys, statistical data, photos, and archival film footage give important glimpses into the lives of children who were too young to leave records of their own. ${ }^{9}$ Definitions 
of modern childhood by historians Paula Fass and Peter Stearns provide a framework for determining how WPA nursery schools helped children. This book is also influenced by those historians of childhood and progressive education who argue that children both shape and are shaped by their schools. ${ }^{10}$ It covers forgotten WPA nursery school leaders like Langdon who, as members of the first significant cohort of American women with $\mathrm{PhDs}$, struggled valiantly to achieve universal preschool for the entire nation. ${ }^{11}$

Since the early 1970s, a handful of scholars have painted positive pictures of the program and written of its demise, but their findings have been drowned out by the majority of scholars who disparage it. Some fail to analyze the program for reasons often tied to their chosen focus. Women's historians, both those of the 1980s, who focus more on working women, and those of the 1990s, who tend to emphasize American motherhood, follow the lead of those who wrote in the early 1970s and argued that World War II played a greater role than the New Deal in transforming American society and culture. ${ }^{12}$ More recently, women's historians have shifted emphasis away from World War II to a re-examination of women in postwar America. Historians of progressive education focus largely on K-12 reform, and scholars of early childhood write about educational pioneers, often without historical context. New Deal historians continue to ignore the program, and most Cold War studies of progressive education fail to explore policy ties to the New Deal. ${ }^{13}$ Historians of children, especially William Tuttle and Barbara Beatty, do call attention to the program's significance, however, and this book builds on their insights.

Head Start and President Nixon's veto of the 1971 Comprehensive Child Development Act (CCDA) awakened interest in the history of childcare. ${ }^{14}$ Early childhood educators and psychologists, eager to retrieve their professions' pasts, were the first to re-examine the history of nursery schools. In 1971, James Hymes, one of the architects of Head Start, interviewed nursery school pioneers. The two histories that emerged reveal little awareness that the nursery school and child development professions shared a common history before World War II..$^{15}$

Second-wave feminists also looked to the past to help explain why the federal government had not yet created a national program of childcare. Shirley Chisholm, the African American congresswoman who ran for president in 1972 and was a former New York City nursery school teacher, argued on the floor of the House of Representatives that "discrimination against women and indifference to the poor are at the center of this country's reluctance to expand its support for childcare programs." 16 Yet when scholars discuss WPA schools, they often show how little they know about the program, describing it as the antithesis of what it really was:

The function of WPA nurseries, then, was not to educate the child, or to free the woman for work, or to bring social case work to the families, but simply to provide jobs to teachers and hot meals to poor 
children. As one would expect, turnover in both clients and staff was very high, facilities were inadequate (the basements of schools or public buildings), and the entire effort was really a minor venture in relief giving. ${ }^{17}$

A younger generation of women's historians has focused on women's employment during the Great Depression and World War II, but the WPA nursery school program largely escapes their attention. Alice Kessler-Harris takes issue with the argument that World War II was a turning point, but she dismisses the entire WPA in a sentence because "relief" women were paid lower salaries than men. She concentrates instead on painting a more complex picture for World War II-era childcare, which she concludes "never worked well." ${ }^{18}$ Lynn Weiner dismisses the WPA nursery school program in similar fashion. She too describes it as what it was not:

These nurseries were not geared towards the needs of mothers who worked or toward the educational and psychological needs of children. Rather, their avowed function was to provide employment for teachers, nurses, nutritionists, cooks, janitors, and clerical workers. With the end of the New Deal, the WPA nurseries lost their federal funding and began to close. ${ }^{19}$

Interdisciplinary scholarship on young children brings new life to the childcare discussion. The psychologist Emily Cahan asserts that the United States always had a two-tier system for educating young children: kindergartens and nursery schools for the wealthy, day nurseries for the poor. Her 1989 work argues that only wealthy children benefited from group care, and she consigns WPA nursery schools to an ambiguous status. They were neither day nurseries nor nursery schools, but poverty-track institutions of "narrow scope, uneven quality, and limited availability of health, nutrition, and childcare services." ${ }^{20}$ William Tuttle renews interest in childcare politics; Hamilton Cravens provides important detail about George Stoddard's role in the WPA nursery school program; and Kriste Lindenmeyer's revisionist study touches on the animus of the CB toward the WPA. ${ }^{21}$

Barbara Beatty's 1995 book addresses why the United States does not have universal preschool. ${ }^{22}$ Despite pointing to the uneven quality of WPA nursery schools at the local level, she resurrects the reputation of the WPA nursery school program in the roughly fifteen pages she devotes to it. ${ }^{23}$ Making explicit her assumption that early childhood education benefits young children, she highlights the program's goal of achieving permanency within the public-school system. Most important, she argues that the World War II childcare program picked up the key threads of its WPA predecessor, noting that program director Grace Langdon had led the WPA nursery school program for nearly a decade before assuming control of the Lanham daycare program for working mothers in World War II. 
Sonya Michel focuses on the Washington battle over childcare during the war, trying to get a better sense of how rival agencies like the CB impeded the efforts of Grace Langdon and her boss, Florence Kerr, to provide group childcare to working mothers. Seeing the WPA's Langdon and Kerr as surrounded by hostile forces, including other women at the $\mathrm{CB}$, Michel asserts that:

the failure of child care policy should not be attributed solely to a "male conspiracy" to keep women out of the labor force but also to a politics of maternalism which accepted the notion that mothers properly belonged at home with their children. ${ }^{24}$

Focusing on how these schools met the childcare needs of working mothers, Michel explains their failure to take root in postwar society by their inability to serve enough women. Unlike earlier historians who dismiss the program to focus on Lanham, Judith Sealander highlights WPA nursery schools and relegates Lanham to a footnote. ${ }^{25}$ In the end, Sealander minimizes the importance of the WPA nursery school program because it did not survive World War II. Her overall point is to show that New Deal reform has failed young children.

Others ignore the WPA program entirely. Susan Douglas and Meredith Michaels focus on the political battles fought over childcare in the early 1970s. ${ }^{26}$ In their feisty chapter, "Dumb Men, Stupid Choices—or Why We Don't Have Childcare," they relate these battles to the wartime Lanham children's centers, which they depict in a favorable light, though they leave connections between the WPA nursery school program and Lanham unexplored. Natalie Fousekis argues that a coalition of early childhood educators, New Deal liberals, labor unions, African Americans, mainstream women's groups, Communist Party members, left feminists, and working mothers helped ensure that public preschools remained in California after the war. ${ }^{27}$ In important ways, this discussion of a leftist coalition complements my own research. But she, too, leaves the WPA nursery school program unexamined, even though many of the California women she highlights began their early childhood education careers in WPA nursery schools.

Dismissal of the WPA nursery school program because of its relatively brief tenure helps explain the program's absence from the otherwise rich historiography on progressive education. It is a grievous omission. Although progressive educators were among the staunchest allies of the WPA nursery schools at both the national and local levels, they do not appear, and the program receives only the barest mention, in more than fifty works in this literature. ${ }^{28}$ WPA educational programs and their administrators hardly make the history books.

A deeply ingrained gender bias is one reason for erasure. Early childhood educators have recognized this for some time, and the pioneering effort 


\section{Introduction}

of James Hymes in the early 1970s began the reclamation of forgotten leaders. ${ }^{29}$ Yet this fairly wide body of literature has been ignored by most historians of progressive education, who continue to emphasize continuity over change in educational practices. Some, like Larry Cuban and Arthur Zilversmit, argue that teachers tend to teach the way they themselves have been taught, and that for all the talk of reform, little real change has occurred in the classroom. ${ }^{30}$ No wonder there is little inclination to look for innovation in the historical record when so many apparent examples of stasis abound.

Historians have long considered George Counts, professor of education at Columbia University, the quintessential radical progressive educator of the 1930s because he protested the evils of capitalism and continued to emphasize the potential of education to effect social reform. ${ }^{31}$ Yet because they perceive progressive programs as devolving into "Life Skills Adjustment" after World War II, they discount the revolutionary import of his ideas. Noting, too, that George Counts became more conservative with age, historians have tended to view him and other 1930s radical educators as men filled with hot air who dared not act on their words. ${ }^{32}$ Historians also emphasize that K-12 educators did not necessarily heed Counts' call to action, characterizing the great majority of teachers during the Depression as being mostly meek women fighting to hold onto their low-paying jobs and more interested in social control than in social revolution. Concluding that Counts personified the ivory tower intellectual who preached while teachers in the trenches concerned themselves with practical issues, historians often focus on whether progressive education ever really took root in the public schools and, if it did, if it ever really helped children.

Since Lawrence Cremin published his magisterial Transformation of the School in 1961, historians have tended to emphasize secondary education and exclude discussion of early childhood reform efforts like the WPA nursery school program..$^{33}$ Because of this emphasis on secondary school reform, Cremin's analysis of early childhood education as something apart from the public-school system goes unchallenged. ${ }^{34}$ Cremin depicts Bank Street educator Caroline Pratt as his quintessential "Sentimentalist," the sort of interwar "child-centered" educator who let children do their own thing. What Cremin leaves out in his retelling is that socialist Bank Street educators like Pratt participated in a wide array of reform activities during the interwar period, including the WPA nursery school program..$^{35}$ Influenced by the increasingly conservative views of his former dissertation advisor, George Counts, Cremin focuses on private school education. In so doing, he renders invisible the efforts of Counts' own colleagues at Columbia University during the 1930s-especially WPA nursery school program leaders Grace Langdon, Patty Smith Hill, and Lois Meek Stolz. ${ }^{36}$

Chapter 1, "WPA Nursery Schools as Educational Reform," is an intellectual history of the WPA nursery school program and lays the foundation 
for the argument that the program was an important New Deal achievement. It demonstrates that WPA nursery school leaders were influential progressive educators, intent on expanding educational opportunity. ${ }^{37}$ Program administrators devised a classroom curriculum devoted to the "whole child" and became pioneers in the scientific study of young children. They helped create two new interdisciplinary disciplines: child development and home economics. They (not John Watson, not Arnold Gesell, and not Benjamin Spock) ushered in the field of parent education. They encouraged cooperative play among preschoolers and offered education to all children, no matter what their background. Their response to the rise in totalitarianism abroad involved teaching the youngest of citizens to get along in a nonauthoritarian group setting. The chapter examines how program leaders developed their reform impulse within the context of the interwar progressive education movement and the ways they worked to make WPA nursery schools a permanent part of public schools. It concludes by exploring their belief that early childhood education strengthened democracy. Without calling for revolution, WPA nursery school leaders created a daring group care ideology that hoped to create a new social order.

Chapter 2, "American Modernism and the WPA Nursery School Curriculum," analyzes the WPA nursery school program's material culture. It moves beyond the thinking of leaders to focus on actual classroom practice and teacher training. The program aimed at enabling young children to flourish in the industrialized and urban world of the Great Depression, embracing modernism in this quest. Influenced by historian Robert Rydell's understanding that American modernism "was about the substance and meaning of modern life itself," I argue that sympathy for modern architectural forms, the modern mother working outside the home, and modern technology provided a framework for understanding the WPA's own research conclusions: young children learn best when they play with peers in large open spaces. ${ }^{38}$ Emphasizing that program leaders designed a curriculum that incorporated cutting-edge ideas in child development, the chapter explores how leaders articulated the program's primary purpose-children's healthy development-and investigates how the schools promoted young children's physical as well as their emotional well-being. The program held that young children benefited because WPA nursery schools:

- assisted mothers without replacing them

- attended to children's emotional, physical, and social well-being

- celebrated freedom of choice with play materials

- promoted gender equality and cultural pluralism

- provided consistent, yet flexible, daily routines in spacious built environments.

Chapter 3, "The WPA Nursery School and the Community," highlights the program's popularity at the local level and shows the program's 


\section{Introduction}

success in fostering healthy development in children and helping families survive hard times. The chapter argues that schools thrived at the local level because they enjoyed strong community support. The chapter examines the depth and breadth of the program as shown by statistical evidence. It also provides further contextualization for the famed Clark doll tests carried out in WPA nursery schools, the experiments that helped convince the Supreme Court that separate was inherently unequal as it reached its 1954 decision in Brown v. Board of Education. It then explores how the program cultivated community outreach through parent education and concludes by looking at how WPA nursery schools provided a space for community activism in both rural and urban areas. ${ }^{39}$ Local communities, especially parents, were motivated by the desire to help small children and participated in letter-writing campaigns to save the schools, pushed for public kindergartens when federal appropriations for the WPA program were cut, and transformed some WPA nursery schools into parent cooperatives after federal funding ceased altogether.

Chapter 4, "In Time of War," explores the political tale of the program in its waning years, when its efforts to create a more inclusive society prompted several agencies in Washington to threaten its very existence. It offers a fresh interpretation of how rival federal agencies undermined the WPA nursery schools and obstructed the program's efforts to establish public nursery schools. When the federal government, preoccupied with war, turned away from New Deal reform, Grace Langdon remained confident that WPA nursery schools would become permanent because of the high level of support the program enjoyed at the local level. She fought off federal agency attempts to take over WPA nursery schools and succeeded in transforming many of the 1,500 WPA nursery schools into Lanham children's centers, which remained in operation under her leadership until the end of World War II. Even after the war, Langdon thought she could create a new interdisciplinary federal children's agency that would implement universal preschool. By contrast, the $\mathrm{CB}$, long celebrated as the outstanding advocacy organization for children, did not always share the WPA's views of the needs and best interests of preschoolers. Despite the accomplishments of the WPA program, CB chief, Katherine Lenroot, remained ideologically opposed to group care for young children. From 1942 on, she tried to wrest control of the program away from Langdon, promoting counseling for working mothers and foster care for young children. She did not succeed in dismantling the WPA program, however, because Langdon enjoyed support from powerful New Deal women. ${ }^{40}$ This chapter delineates how WPA nursery schools became identified with childcare for working mothers in defense industries. It then investigates how the CB and other rival agencies discredited the WPA nursery school program when they wanted control over childcare options for working mothers. It concludes by examining the role of WPA nursery 
school leaders in the most important childcare battle during wartime, the Thomas Bill hearings of 1943, which became part of the willful erasure of program accomplishments by political rivals. ${ }^{41}$

Chapter 5, "Buried Treasure," examines the program's legacy and develops further the book's contention that the program was willfully buried. It argues that erasure of program accomplishments increased dramatically after 1945. Group care for young children became ever more suspect, and prominent supporters fell victim to red-baiting. Other program leaders proved unwilling (and/or unable) to capitalize on their New Deal accomplishments, retreating largely into the private sector. Grace Langdon moved away from Washington, DC, for instance, to begin her postwar career as a toy consultant. George Stoddard, a fierce proponent of the program, gave up writing about early childhood education altogether, although he stayed active in higher education despite brushes with McCarthyism. Remnants of the program's achievements remained in wealthy private schools like Bank Street, in university nursery schools, in middle-class parent cooperative preschools, and in California's children's centers. ${ }^{42}$ Although relatively few former WPA nursery school leaders worked directly with Head Start, some of the program's ideals inspired the 1971 CCDA. The chapter concludes with a brief remembrance of Langdon who, in the final years of her life, worked to bring early childhood education to First Nations in Arizona. In 1970, Langdon's death brought no recognition from the larger nursery school community. A year later, President Nixon, in vetoing the CCDA, made clear that his administration would not support "communal approaches to child rearing." ${ }^{43}$ Both Langdon's lack of recognition and Nixon's anti-communist fear of group care were rooted in the Red Scare's contribution to the demise of the WPA nursery school program.

As Grace Langdon scrambled to finish her final report of the program midway through 1943, she lamented:

It is unfortunate that figures are not available to show accurately the scope of the nursery school program throughout the entire period of its operation. Such figures would be of historical interest. They would also be of significance in planning any future program on a nationwide basis. $^{44}$

Aware of the pitfalls faced because the program was part of the WPA, which she called a "national social experiment over which controversy raged" and frustrated by her own inability to control "procedures governing program operation," Langdon concluded her report with the words, "the true evaluation of the results of the program must therefore wait until time has thrown them into clearer relief." Seventy-five years in the waiting, here is one attempt to get the facts and the chronology straight. A reckoning with this country's first attempt at universal preschool is long overdue. 


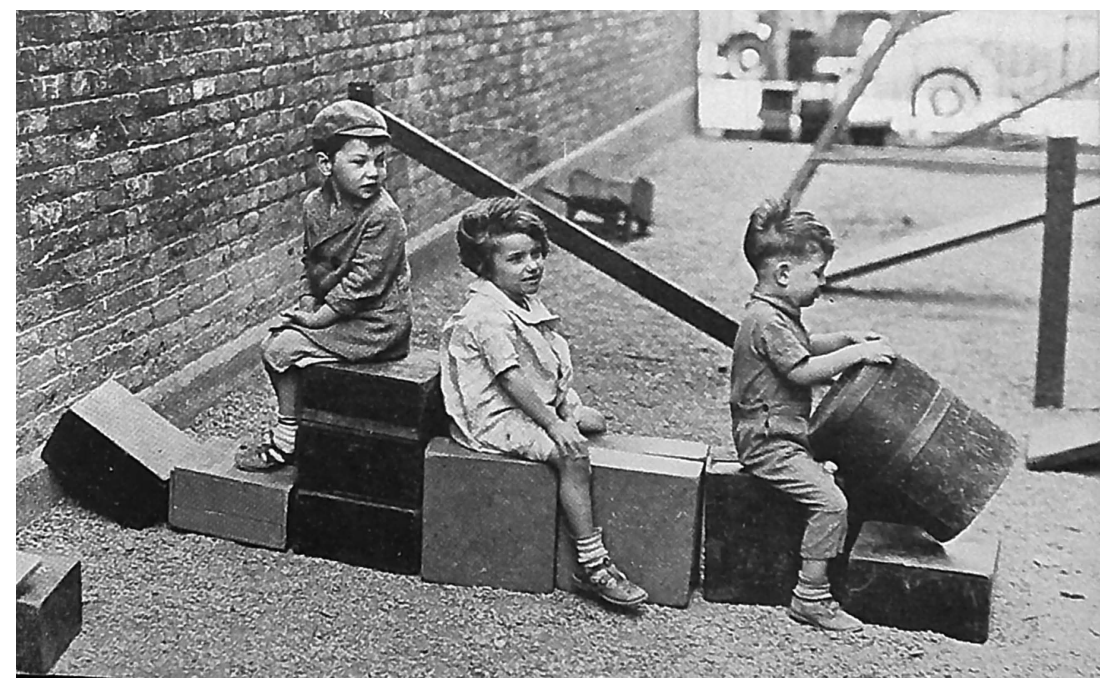

Figure 0.1 Young Children Playing 45

\section{Notes}

1. The WPA nursery school program underwent several name changes from 19331943. It was officially called the Emergency Nursery School program during its earliest years. Then it became known as the WPA nursery school and parent education program (1937-1938), the WPA family life program (1938-42), and finally the WPA Child Protection program (1942-1943). After the Federal Emergency Relief Agency (FERA) became part of the WPA in late spring to early summer 1935, the use of the term WPA nursery school was commonly used.

2. Langdon safeguarded the high quality of WPA nursery schools during her tenure as national director from 1934-1943. As she wryly commented, "It has been assumed that the continuous charge leveled at the program that it did not serve all the children who needed it was a tacit tribute to the worth of the services." See Grace Langdon and Isabel Robinson, The Nursery School Program, 1933-1943: Record of Program Operation and Accomplishment: Division of Service Projects: WPA, Federal Works Agency (Washington, DC, 1943) 40. This book is also the first to provide sustained analysis of the interwar nursery school movement since 1950. See William Jordan, “The History, Scope and Prospects for the Future of the Nursery School Movement" (PhD dissertation, Harvard University, 1950). Local studies of WPA nursery schools include: Annette Moser Hodess, A Study of the History of the WPA Nursery Schools of Boston (PhD dissertation, Boston University, 1983); George Otey, "New Deal for Oklahoma's Children: Federal Day Care Centers, 1933-1946" Chronicles of Oklahoma 62 (1984) 296-311; and Lynn Burlbaw, "An Early Start: WPA Emergency Nursery Schools in Texas, 1934-1943" American Educational History Journal 36 (2009) 269-298.

3. A wide range of women reformers supported WPA nursery schools, including New Dealer Eleanor Roosevelt, Women's International League for Peace and Freedom (WILPF) and CIO leader Eleanor Fowler, National Youth Administration (NYA) 
and CIO women's auxiliary leader Susan B. Anthony II, anthropologist Margaret Mead, African American civil rights activist Mary McLeod Bethune, and journalist Eunice Fuller Barnard. In addition, the program elicited strong support from men, including progressive educator Goodwin Watson, New Dealer Aubrey William, journalist and United Electrical labor leader Cedric Fowler, parent educator Ralph Bridgman, African American civil rights activist and educator A. W. Dent, and United Automobile Workers (UAW) labor leader Victor Reuther. They were all targeted by anti-communists after World War II.

4. In her widely cited work, historian Kriste Lindenmeyer concludes:

During the Great Depression, Congress had funded the (WPA) Lanham Act, which provided federal funds to establish day nurseries. But the Lanham Act was primarily a welfare measure designed to furnish jobs for unemployed teachers and other child welfare workers. The program's benefits for working mothers and their children were secondary or even nonexistent in the minds of many. The placement of the first federal day care program with the WPA, and not the Children's Bureau, is one indication of the general attitude concerning such programs.

See her "A Right to Childhood": The US Children's Burean and Child Welfare, 1912-1946" (1997) 217. However, Title II of Lanham (the Community Facilities Act) was not enacted until 1941, its funds for nursery schools did not become available until 1942, and only for a brief moment (in 1943) would it have been accurate to use the same term for both the WPA nursery school program and the Lanham children's centers that followed. Moreover, as educational institutions, WPA nursery schools were not day nurseries, a form of custodial daycare for children of working-class mothers. WPA Director Harry Hopkins stated that the program served multiple purposes: to help children, their families, and the unemployed. To assume, therefore, that children and working mothers could not possibly have been a high priority simply because the WPA was in charge illustrates the anti-WPA bias of nearly all CB evidence.

5. That the use of tainted evidence can yield widely disparate accounts occurred again in 2015. To provide a context for President Obama's mention of universal childcare during World War II, Lily Rothman at Time magazine used CB sources in her portrayal of both the WPA and Lanham programs. By contrast, Jennifer Ludden at NPR used WPA/Federal Works Agency evidence. Compare/contrast http://time.com/3676272/sotu-child-care-wwii/ and www.npr. org/2015/01/24/379530251/u-s-once-had-universal-child-care-but-rebuildingit-wouldnt-be-easy.

6. Works that guide my analyses include: Howard Dratch, "Politics of Child Care in the 1940s" Science and Society 38 (Summer 1974) 167-204; Ellen Schrecker, No Ivory Tower: McCarthyism and the Universities (1986); Beatrix Hoffman, The Wages of Sickness: The Politics of Health Insurance in Progressive America (2001); Michael Ybarra, Washington Gone Crazy: Senator Pat McCarran and the Great American Communist Hunt (2004); Landon Storrs, The Second Red Scare and the Unmaking of the New Deal Left (2013); and David Price, Cold War Anthropology: The CIA, the Pentagon, and the Growth of Dual Use Anthropology (2016).

7. I rely heavily on collections in more than fifteen different archives around the country with holdings on the WPA nursery school program, and have obtained additional primary material online and through interlibrary loan. Archives include: National Archives, RG-69 (NARA) in College Park, MD; ACEI archives at the University of Maryland, College Park, MD; Pacific Oaks archives in Pasadena, CA; Barbara Greenwood Collection in Pomona, CA; Long Beach Public Library, Special Collections in Long Beach, CA; Rosalie Blau Collection (RB, 


\section{Introduction}

CSUN), 1921-1987, California State University, Northridge: Urban Archives; Filson Club in Louisville, Kentucky; Teachers College Archives at Columbia University, New York City; Helen Gahagan Douglas papers at the University of Oklahoma, and Merrill-Palmer Institute: Edna Noble White Records (ENW), Walter P. Reuther Library of Labor and Urban Affairs, Wayne State University, Detroit. Documents also obtained from the Alice Keliher papers, NYU archives; Progressive Education Association Papers, University of Illinois; Lois Meek Stolz papers, National Library of Medicine archives; Florence Kerr collection, Grinnell College; NAEYC special collections, Indiana State University; Rose Haas Alschuler Papers at University of Illinois at Chicago; FWA scrapbooks at the Library of Congress; New York World's Fair Records, New York Public Library Archives and Manuscripts; Floyd Dell Papers, Newberry Library, Chicago; and Church League of America Collection at the Robert F. Wagner Labor Archive, New York University. Important online sources include congressional hearings, small-town newspapers, and the oral histories of Florence Kerr and the Society for the Research in Child Development.

8. Interdisciplinary studies of children that inform my research include Karin Calvert, Children in the House: The Material Culture of Early Childhood, 16001900 (1992); William Tuttle, Daddy's Gone to War: The Second World War in the Lives of America's Children (1993); Gary Cross, Kids' Stuff: Toys and the Changing World of American Childhood (1997); Norman Brosterman, Inventing Kindergarten (2002); and Howard Chudacoff, Children at Play: An American History (2007).

9. Thomas Schlereth has argued that objects used by children are among the best sources for describing the subjective experience of childhood. See "The Material Culture of Childhood: Problems and Potential in Historical Explanation" Material History Bulletin 21 (1985) 1-14. I hope that the reproduced images help reclaim the voices of young children, whom historian Barbara Beatty has called among "the most silent and silenced of historical actors."

10. According to Paula Fass, a modern child was "a separate being whose nature was not pre-adult, but non-adult, and for whom play rather than work was the defining environment." See also N. Ray Hiner and Joseph M. Hawes, eds., Growing Up in America: Children in Historical Perspective (1985); Mary B. Lane, Our Schools-Frontline for the 21st Century: What Schools Must Become (1998); and Peter Stearns, "The Dilemma of Children's Happiness" Childhood in World History (2017, 3rd ed.) 166-172. Psychological theories for why young children's healthy development depends upon early childhood education inform my research as well. Philosophical influences include John Dewey's Democracy and Education (1916). Dewey argues that public education is a requisite for a more just and equitable society, and he influenced many of those described below.

11. For forgotten New Deal women, see especially Robyn Muncy, Relentless Reformer: Josephine Roche and Progressivism in 20th Century America (2015); Ida Jones, Mary McLeod Bethune in Washington, D.C: Activism and Education in Logan Circle (2013); Kirstin Downey, The Woman Behind the New Deal: The Life and Legacy of Frances Perkin (2009); and Martha Swain, Ellen S. Woodward: New Deal Advocate for Women (1995). Eleanor Roosevelt biographers rarely mention her support of WPA nursery schools. See, for example, Doris K. Goodwin, No Ordinary Time (1994); Robert Cohen, Dear Mrs. Roosevelt: Letters from the Children of the Great Depression (2002); and Blanche Wiesen Cook, Eleanor Roosevelt: Volume 2, 1933-1938 (1999) and Volume 3, 19391962 (2016). In Defenseless Under the Night: The Roosevelt Years and the Origins of Homeland Security (2016), Matthew Dallek details Eleanor Roosevelt's efforts in creating the Office of Civilian Defense. In Feminism Unfinished (2014), Dorothy Sue Cobble uses the term social justice feminism to describe leftist 
women like Eleanor Roosevelt who wanted to keep protective legislation for women in place and so did not support the Equal Rights amendment after World War I. In The Second Red Scare and the Unmaking of the New Deal Left (2013), Landon Storrs uses left feminists to describe women and men who pursued a vision of women's emancipation that also insisted on class and racial justice. Both terms apply to WPA nursery school program leaders and their supporters.

12. See especially, Richard Polenberg, War and Society: The United States, 19411945 (1972); and William Chafe, American Woman: Her Changing Social, Economic, and Political Roles, 1920-1970 (1972).

13. In Freedom from Fear: The American People in Depression and War, 19291945 (1999), David Kennedy argues that "achieving security was the leitmotif of virtually everything the New Deal attempted." Like many New Deal scholars, Kennedy does not mention the WPA nursery school program. Instead, he focuses solely on World War II child care, perpetuating the myth that World War II women were simply not interested in group care. To his credit, Kennedy integrates both time periods (depression and war) into his overall narrative and eschews the ongoing debate as to which had a greater influence on postwar society. In a groundbreaking reassessment of the WPA, Bring Back the WPA: Work, Relief, and the Origins of American Social Policy in Welfare Reform (Spring 1998), Edwin Amenta argues that too much emphasis has been placed on the 1935 Social Security Act and not enough on other reform measures FDR put in place to achieve security. Recent overviews on the WPA's anti-communist critics include Nick Taylor, American-Made: Enduring Legacy of the WPA-When FDR Put the Nation to Work (2009); and Sandra Opdycke, The WPA: Creating Jobs and Hope in the Great Depression (2016).

14. See Barbara Harned, "Relationships Among the Federally Sponsored Nursery Schools of the 1930s, the Federally Sponsored Day Care Program of the 1940s and Project Head Start" (PhD dissertation, Rutgers University, 1968). For evidence of renewed interest in the built environment of the nursery school, see Jonathan Hale, "Child Care Centers" Architectural Record 151 (April 1972) 127-142.

15. D. Keith Osborn, Early Childhood Education in Historical Perspective (1975) and Robert Sears, "Your Ancients Revisited: A History of Child Development" Review of Child Development Research 5 (1975). Hymes also self-published his interviews as Living History Interviews: Books 1-3 (1979).

16. Pamela Roby, ed., Child Care-Who Cares? Foreign and Domestic Infant and Early Childhood Development Policies (1973) xii.

17. Sheila Rothman, "Other People's Children: The Day Care Experience in America” Public Interest 30 (Winter 1973) 11-27 [quote is from page 20]. See also Margaret Steinfels, Who's Minding the Children: History and Politics of Day Care in America (1973) 68.

18. Alice Kessler-Harris, Out to Work: A History of Wage-Earning Women in the US (1982) 284-285.

19. Lynn Weiner, From Working Girl to Working Mother (1985) 134.

20. Emily Cahan, Past Caring: A History of U.S. Preschool Care and Education for the Poor, 1820-1965 (1989) 27. Cahan cited both Chafe 1972 and Robert Tank, "Young Children, Families and Society in America since the 1820s: The Evolution of Health, Education, and Child Care Programs for Preschool Children" (PhD dissertation, University of Michigan, 1980). Although Cahan clearly felt herself in debt to Tank (he coined the term poverty-track institution, for instance), his work has been supplanted by Cahan and the other scholars who followed in her wake.

21. Tuttle's close analysis in Daddy's Gone to War (1993) and his follow-up 1995 article, "Rosie the Riveter and Her Latchkey Children," yields the following 
claim: "The United States was probably closer to having a national child day care policy in 1945 than it is today." Referencing Louis Covotsos's 1976 dissertation on the CB in "A Right to Childhood": The US Children's Bureau and Child Welfare, 1912-46 (1997), Kriste Lindenmeyer asserts "He criticizes the female administrators and supporters of the bureau for being more interested in maintaining control and power for themselves than in developing an effective comprehensive child welfare policy. This judgment seems somewhat harsh." I am not convinced it was harsh. Hamilton Cravens' Before Head Start (1993) builds on the work of Steven Schlossman and Alice Smuts. See also Rose Kundanis, "Rosie the Riveter and the Eight-Hour Orphan: The Image of Child Day Care during WWII" in M. Paul Holsinger and Mary Anne Schofield, eds., Visions of War: WWII in Popular Literature and Culture (1992) and Geraldine Youcha, Minding the Children: Child Care in America from Colonial Times to the Present (1995).

22. Barbara Beatty, Preschool Education in America: The Culture of Young Children from the Colonial Era to the Present (1995).

23. Like Beatty, Elizabeth Rose argues for the uneven quality of WPA nursery schools in A Mother's Job: The History of Day Care, 1890-1960 (1999). I think Beatty and Rose have overplayed this notion about the uneven quality of the schools. The evidence they used can also support an assessment of the schools as generally having been quite good. Langdon was a perfectionist; she tended to point out weaknesses in her field reports before she mentioned strengths. Primary evidence from a wide variety of sources generally suggests overall high quality. Rose builds on and supplants Linda Goldmintz, "The Growth of Day Care, 1890-1946" (PhD dissertation, Yeshiva University, 1987).

24. Sonya Michel, Children's Interests/Mothers'Rights: The Shaping of America's Child Care Policy (1999) 3. See also her online history https://socialwelfare. library.vcu.edu/programs/child-care-the-american-history/.

25. Judith Sealander, The Failed Century of the Child: Governing America's Young in the 20th Century (2003).

26. Susan Douglas and Meredith Michaels, The Mommy Myth: The Idealization of Motherhood and How It Has Undermined Women (2004).

27. Natalie Fousekis, Demanding Child Care: Women's Activism and the Politics of Welfare, 1940-1971 (2011). See also Emile Stoltzfus, Citizen, Mother, Worker: Debating Public Responsibility for Child Care after the Second World War (2003) and Charles Dorn, American Education, Democracy, and the Second World War (2007).

28. One exception: David Tyack, Robert Lowe, and Elisabeth Hansot give a positive one-paragraph portrayal in Public Schools in Hard Times (1984), in part because they rely upon two sources that use WPA evidence: Doak Campbell, Frederick Bair, and Oswald Harvey, Educational Activities of the Works Progress Administration (Washington, DC: US Government Printing Office, 1939); and Harry Zeitlin, "Federal Relations in American Education, 1933-1943: A Study of New Deal Efforts and Innovations" (PhD dissertation, Columbia University, 1958).

29. Recent works include: Ruby Takanisihi, "Federal Involvement in Early Education (1933-1973): The Need for Historical Perspectives" in Lilian Katz, ed., Current Issues in Early Childhood Education (1977); Carolyn Burns, "A Comparative Study of the History of Day Care Centers and Nursery Schools in the United States" (Bank Street master's thesis, 1979); Millie Almy, ed., Profiles in Childhood Education, 1931-1960 (1992); Maxine Seller, ed., Women Educators in the United States, 1820-1993 (1994); Kathleen Tebb, ed., Thoughtful Reflections for Future Directions: Los Angeles County Child Care Oral History (1996); Barbara Ruth Peltzman, Pioneers of Early Childhood Education: A Bio-Bibliographical Guide (1998); Dorothy Hewes, "It's the Camaraderie": 
A History of Parent Cooperative Preschools (1998); Jennifer Wolfe, Learning from the Past: Historical Voices in Early Childhood Education (2000); V. Celia Lascarides and Blythe Hinitz, A History of Early Childhood Education (2000), NAEYC at 75: Reflections on the Past, Challenges for the Future (2001); Jane Fowler Morse, "Ignored but Not Forgotten: The Work of Helen Bradford Thompson Woolley" NWSA Journal 14 (Summer 2002) 121-147; Ann Taylor Allen, "Gender, Professionalization, and the Child in the Progressive Era: Patty Smith Hill, 1868-1946" Journal of Women's History 23 (Summer 2011) 112-136; Susan Adler and Jeanne Iorio, "Progressive Teachers of Young Children: Creating Contemporary Agents of Change" International Journal of Progressive Education 9 (November 2013); Blythe Hinitz, ed., Hidden History of Early Childhood Education (2013); Patricia Giardiello, Pioneers in Early Childhood Education: The Roots and Legacies of Rachel and Margaret McMillan, Maria Montessori and Susan Isaacs (2014); NAEYC, Young Children-Our Proud Heritage series. Examples include: “Abigail Eliot and Margaret McMillan-Bringing the Nursery School to the United States" (May 2016).

30. Larry Cuban, How Teachers Taught: Constancy and Change in American Classrooms, 1890-1990 (1993); and Arthur Zilversmit, Changing Schools: Progressive Education Theory and Practice, 1930-1960 (1993). See also Jonathan Zimmerman, "Why Is American Teaching So Bad" (December 4, 2014) in The New York Review of Books; and Dana Goldstein, Teaching Wars: A History of America's Most Embattled Profession (2014).

31. See, for example, Lawrence Cremin, The Transformation of the School: Progressivism in American Education, 1876-1957 (1962); C.A. Bowers, The Progressive Educator and the Depression: The Radical Years (1969); and Helen Horowitz, "The Progressive Education Movement After WWI” History of Education Quarterly 11 (Spring 1971) 79-84.

32. See Marjorie Murphy, Blackboard Unions: The AFT and the NEA, 1900-1980 (1990). Many women, including WPA teachers, were involved in the American Federation of Teachers (AFT). When it was red-baited, George Counts was brought in to try to purge the communists, 1939-1941.

33. See, for example, John Rury, "Transformation in Perspective: Lawrence Cremin's Transformation of the School" History of Education Quarterly 31 (Spring 1991) 66-76; and Diane Ravitch, Left Back: A Century of Failed School Reform (2001).

34. One notable exception remains Kathleen Weiler. See especially her Democracy and Schooling in California: The Legacy of Helen Heffernan and Corinne Seeds (2011).

35. See Joyce Antler, Lucy Sprague Mitchell: The Making of a Modern Woman (1987). In addition to Pratt, Bank Street Educators involved in WPA nursery schools included Harriet Johnson, Agnes Snyder, and Jessie Stanton.

36. Hill gets referenced as a kindergarten (but not nursery school) reformer in two sentences $(173,176)$. Langdon and Stolz are not cited at all. Cremin mentions James (Jimmy) Hymes and George Stoddard in passing, but he does not tell of their involvement in the WPA nursery school program.

37. The nursery school movement itself may be a little-known tale of American socialism. According to Ilse Forest in Preschool Education: A Historical and Critical Study (1927), educator Grace Owen was Robert Owen's granddaughter. Because she helped introduced the nursery school concept to American women, the American and British nursery school movement might well be characterized as literal descendants of Robert Owen's utopian vision. My assessment is based also on correspondence with Jane Fowler Morse, Helen T. Woolley's granddaughter and Eleanor Fowler's daughter. 


\section{Introduction}

38. See Robert Rydell, Designing Tomorrow: America's World Fairs of the 1930s (2010) 7-8. Daniel Singal, "Towards a Definition of American Modernism" American Quarterly 39 (Spring 1987) 7-26, also highlights how modernism influenced progressive education.

39. I believe WPA nursery school evidence calls into serious question Anthony Badger's assertion in The New Deal: The Depression Years, 1933-1940 (1989) that "New Deal relief and welfare programs made no attempt to draw on the tradition of urban community organization that came from the settlement houses. ... It would be the 1960s before urban welfare policy with Community Action Programs took up that approach again" (307-308).

40. In addition to Eleanor Roosevelt, staunch supporters included anthropologist Margaret Mead, Representatives Mary Norton (D-NJ) and Helen Gahagan Douglas (D-CA), and CIO labor leaders Eleanor Fowler and Susan B. Anthony II, grandniece of the suffragist. All were red-baited.

41. Susan B. Anthony II called the Thomas Bill hearings "The Battle of the Child" in Out of the Kitchen and into the War: Women's Winning Role in the Nation's Drama (1943).

42. See especially, Joyce Antler, Lucy Sprague Mitchell: The Making of a Modern Woman (1987); Mary B. Lane, Our Schools-Frontline for the 21st Century: What Schools Must Become (1998); Robyn Muncy, "Cooperative Motherhood and Democratic Civic Culture in Postwar Suburbia, 1940-1965" Journal of Social History 38 (Winter 2004) 285-310; and Natalie Fousekis, Demanding Child Care: Women's Activism and the Politics of Welfare, 1940-1971 (2013).

43. See Kimberly Morgan, "A Child of the Sixties: The Great Society, the New Right, and the Politics of Federal Child Care" The Journal of Policy History 13 (2) (2001) 215-250. For a pithy overview, which relates the CCDA to Obama's call for universal preschool in 2013, see the New York Times editorial by Gail Collins, "The State of the 4-Year-Olds" (February 14, 2013). For more detailed discussion, see Elizabeth Palley and Corey Shdaimah, In Our Hands: The Struggle for US Child Care Policy (2014). See also an excellent NPR article by Jennifer Ludden, www.npr.org/2016/10/13/497850292/ how-politics-killed-universal-childcare-in-the-1970s.

44. Grace Langdon and Isabel Robinson, The Nursery School Program, 19331943: Record of Program Operation and Accomplishment: Division of Service Projects: WPA, Federal Works Agency (Washington, DC, 1943) 38. This manuscript of over two-hundred pages is un-paginated.

45. Helen Post, An Auto Ride: In Curriculum Guides for Teachers of Children from Two to Six Years of Age (New York: John Day, 1936) 148. See also the Helen Post Papers-Amon Carter Museum of American Art. 